\title{
Improved Paddy Straw as Ruminant Feed: A Review
}

\author{
Sheikh GG*, Ganai AM, Reshi PA, Sheikh Bilal and Shabir Mir \\ Division of Animal Nutrition, Sher-e-Kashmir University of Agricultural Sciences and Technology of Kashmir, India
}

Submission: January 09, 2018; Published: April 09, 2018

*Corresponding author: Sheikh GG, Sher-e-Kashmir University of Agricultural Sciences and Technology of Kashmir Shuhama, Alusteng, Srinagar-190 006, Jammu and Kashmir, India, Email: gull2217@gmail.com

\begin{abstract}
Paddy straw is a major agro-residue fed to ruminants in India. Feeding only rice straw does not provide enough nutrients to the ruminants even for maintenance due to the low nutritive value of this highly lignified material containing high concentration of anti-nutrition factors like lignin, silicates and oxalates. Despite the improvements of crop residues through various processing methods such as physical and chemical, the efficient utilization to desirable extent is still awaited. So utilization of paddy straw in association with concept of complete feed along with biological agents is need of the hour to maximize advantage from given feeds in animal production systems.
\end{abstract}

\section{Introduction}

In tropical zones of the world, ruminants depend on grazing on natural pastures usually during summer months when these pastures have abundant biomass or these animals are fed with cut grass and crop residues. Most of these areas face seasonal periods in which there is decrease in availability of herbages in these pasture. There is also reduction in the content of digestible energy and crude protein. In these areas rice straw is abundantly available from paddy cultivation and farmers offer rice straw as the main roughage source to their animals. This is particularly the case in developing Asian countries such as Thailand, Vietnam, Indonesia and India [1]. Approximately $80 \%$ of the world's rice is grown by small scale farmers in many

Table 1: Rice production and byproducts of top 10 rice producing countries in the world in 2013 Calculated data (Adapted from NARC newsletter, 2013).

\begin{tabular}{|c|c|c|c|}
\hline Country & Rice Production (Million t) & Rice Husk (Million t) & Rice Straw (Million t) \\
\hline China & 166 & 38.18 & 74.7 \\
\hline India & 133.51 & 30.71 & 60.08 \\
\hline Indonesia & 51.85 & 11.93 & 23.33 \\
\hline Bangladesh & 38.06 & 8.75 & 17.13 \\
\hline Vietnam & 34.61 & 7.96 & 15.57 \\
\hline Thailand & 27 & 6.21 & 12.15 \\
\hline Myanmar & 21.9 & 5.04 & 9.86 \\
\hline Philippines & 13.17 & 3.03 & 5.93 \\
\hline Brazil & 10.22 & 2.35 & 4.6 \\
\hline Japan & 9.86 & 2.27 & 4.44 \\
\hline
\end{tabular}




\section{JOJ Sciences}

\section{Chemical composition of paddy straw and constraints} in feeding to ruminants

The chemical composition of paddy straw varies between varieties and growing seasons, with higher nitrogen and cellulose contents in early season rice compared to others [5]. Paddy straw contains 25-45\% cellulose, 25-30\% hemicellulose and $10-15 \%$ lignin with low nitrogen, vitamins, minerals and high quantities of silica which hinder the

Table 2: Chemical composition of rice straw.

\begin{tabular}{|c|c|}
\hline Particular (\%) & Range \\
\hline \multicolumn{2}{|c|}{ Chemical composition } \\
\hline DM & $88.00-96.87$ \\
\hline $\mathrm{OM}$ & $83.00-90.00$ \\
\hline $\mathrm{CP}$ & $2.00-6.50$ \\
\hline $\mathrm{CF}$ & $30.00-40.00$ \\
\hline $\mathrm{ADF}$ & $49.00-73.01$ \\
\hline NDF & $39.83-85.00$ \\
\hline NFE & $40.00-46.00$ \\
\hline Hemi-cellulose & $13.00-32.24$ \\
\hline Cellulose & $31.96-60.00$ \\
\hline Ash & $11.00-16.00$ \\
\hline AIA & $3.00-5.00$ \\
\hline ADL & $4.63-13.00$ \\
\hline $\mathrm{Si}$ & $4.25-13.00$ \\
\hline \multicolumn{2}{|c|}{ Major minerals } \\
\hline $\mathrm{Ca}$ & $0.52-2.24$ \\
\hline $\mathrm{P}$ & $0.13-0.39$ \\
\hline K & $0.95-2.21$ \\
\hline $\mathrm{Mg}$ & $0.91-2.35$ \\
\hline $\mathrm{Na}$ & 0.06-0.09 \\
\hline \multicolumn{2}{|c|}{ Minor minerals } \\
\hline $\mathrm{Fe}$ & $0.04-0.45$ \\
\hline $\mathrm{Mn}$ & $0.07-$ \\
\hline $\mathrm{Cu}$ & 0.005 \\
\hline $\mathrm{Zn}$ & 0.02 \\
\hline
\end{tabular}

Compiled from Prasad et al. [39], Singh \& Oosting [52], Shen et al. [49], Van Soest [59], Wanapat et al. [62], Ganai \& Teli [19], Akinfemi \& Ogunwole [4], Hossain et al. [22], Gomma et al. [21], Hussein et al. [23], Sheikh et al. [48]. nutrient availability to rumen microbes and eventually limits the necessary nutrient uptake for a satisfactory performance of the animals [6,7]. Presence of anti-nutritional factors like silicates and oxalates in rice straw with low nutritive value, poor palatability and limited ruminal degradation render paddy straw as non-maintenance type of fodder, so cannot support nutrient requirement of the animals when fed alone $[6,8]$. 
The chemical and mineral compositions of rice straw, cited by different workers, are illustrated in Table 2. Rice straw consists predominantly of cell walls, comprised of cellulose, hemi cellulose, and lignin. To break down these components cellulase, hemi cellulase and ligninase are required [9]. In ruminants cellulase and hemicellulase are produced by rumen microorganisms however, lignin cannot be broken down in the rumen due to the lack of ligninase. Lignin, however, has important effects on livestock production through effects on degradability and feed intake. Theoretically, lignin located between the cellulose micro fibrils is regarded as the most abundant natural aromatic organic polymer that plays a role in resisting compressing forces, providing protection against consumption by insects and mammals, and also inhibiting the rate and degree of microbial degradation [10]. Silica, one element of the rice cell walls, can be present in high concentrations ranging from $5 \%$ to $15 \%$, depending on the rice variety [11] and the availability of this mineral in the soil [12]. Silica reduces palatability and the degradability of rice straw in the rumen due to its direct action in preventing colonization by ruminal microorganisms $[12,13]$. The role of silica on the quality of rice straw was also reviewed by Van Soest [8], in an attempt to put into perspective the problems of silicon metabolism. Besides cell wall polymers, rumen organisms need other nutrients for growth and metabolism.

Since rice straw does not contain enough sugars, amino acids and minerals for efficient microbial growth, feeding ruminants with only rice straw, without any supplementation of other required nutrient sources, will result in poor performance of the animals [14]. The combination of low intake, low degradability, low nitrogen content and an unbalanced mineral composition means that rice straw alone may not even meet the animal's maintenance needs. Poor degradability is caused by a series of factors [9]. The fiber is very difficult to degrade, which is partly an intrinsic characteristic of the straw fiber (higher lignin and silca content). The degradation of the straw fiber is also complicated by the poor functioning of the rumen due to the unbalanced availability of nutrients, the low protein content, the lack of easily available energy and the low content of essential minerals such as phosphorus and sulphur. Hence, due to the low degradability and the poor rate of degradation, animals will tend to consume less. The generally accepted theory of feed intake regulation for poor quality roughages is that the capacity of the rumen to process the feed is the major factor determining voluntary feed intake $[15,16]$. The rumen processing capacity is characterized by rumen fill, the rate of degradation of potentially degradable matter and the rate of passage out of the rumen. Devendra [2] summarized that the main determinants of intake and degradability of rice straw depend on their morphological characteristics, such as the proportion of the different plant parts (leaves and stems), their chemical composition and the distribution of the different chemical components in the tissues, their relative amounts of cell contents and cell walls and the physical and chemical nature of the cell walls. These factors influence the chewing behavior of animals and the extent of fragmentation in the reticulo-rumen. As per Theander \& Aman [17], rice straw contains a relatively high proportion of leaf $(60 \%)$, compared to other cereal straws such as barley (35\%), oats (43\%) and wheat (20-41\%). Vadiveloo [18] reported that leaves of rice straw contain less NDF than the stems, but more ash and acid-insoluble ash, resulting in a lower in vitro dry matter digestibility (IVDMD) of the leaves (50-51\%) compared to the stems (61\%). In goats, Phang \& Vadiveloo [19] observed an in vivo dry matter digestibility of $56.2 \%$ for rice leaf and $68.5 \%$ for the stem. However, treatment with a $4 \%$ urea solution for $21 \mathrm{~d}$ increased the IVDMD of the leaf fraction more than that of the stem fraction [18]. Since rice straw consists of approximately $60 \%$ leaves [20], which are less degradable than stems, improving the feed value of rice straw should focus on improving the degradability of the leaves.

\section{Possible strategies to improve rice straw utilization in ruminants}

Feeding only rice straw does not provide enough nutrients to the ruminants even for maintenance due to the low nutritive value of this highly lignified material. Basically, the key to improving the use of crop residues for ruminants is to overcome their inherent barriers to rumen microbial fermentation. In the case of rice straw, the important factors that restrict bacterial degradation in the rumen are its high levels of lignification and silicification, and its low contents of nitrogen, vitamins and minerals [21]. The high level of lignification and silicification, the slow and limited ruminal degradation of the carbohydrates and the low content of nitrogen are the main deficiencies of rice straw, affecting its value as feed for ruminants [8]. To improve the feeding value of rice straw, it can be treated with different means and methods and other required nutrients can be supplemented in the ration of the animal. Strategies to improve the utilization of rice straw are summarized.

\section{Physical and chemical treatment}

Extensive work has been done to improve nutritive value of crop residues by chemical and physical treatments. In physical treatment crop residues can be ground, soaked, pelleted or chopped to reduce particle size or can be treated with steam or X-rays or pressure cooked. Many of these treatments are not practical for use on small-scale farms, as they require machines or industrial processing. This makes these treatments in many cases economically unprofitable for farmers as the benefits may be too low or even negative [9] By treating rice straw with urea or calcium hydroxide or by supplementing rice straw with protein, the intake, degradability and milk yield can be enhanced as compared to feeding untreated rice straw alone $[22,23]$. In past years, several studies have been reported on 
the physical and chemical characterization and utilization of rice straw as ruminant feed $[5,17,24]$. In addition, numerous methods of physical, chemical and biological treatments have been investigated, including supplementation with other feed stuffs or components in order to improve the utilization of rice straw by ruminants [25-30]. The most commonly used alkaline agents are sodium hydroxide $(\mathrm{NaOH})$, ammonia $\left(\mathrm{NH}_{3}\right)$ and urea. Chemical treatments appear to be the most practical for use at farmers level, the chemicals are relatively cheap and the procedures to use them are relatively simple. However, safety precautions are needed for their use as these chemicals themselves are not harmless. Warly et al. [31] showed in a field trial that a ration of rice straw supplemented with soybean meal increased both degradability and intake. Because of the poor quality of untreated rice straw, supplementation easily can increase milk production, as shown for supplementation with cottonseed meal with an urea molasses- multi-nutrient block [28,32,33] and urea molasses treatment [34].

Rice straw is usually fed untreated without supplements in spite of the fact that many methods for improved utilization of rice straw have been developed and recommended. There are several reasons for farmers not to adopt the already developed methods for improved utilization of straw, such as physical, socio-economic conditions and practical reasons [2].

\section{Biological Methods}

Despite the improvements of crop residues through various processing methods such as physical and chemical, the efficient utilization to desirable extent is still awaited. Hence, it is the need of the hour to utilize these crop residues available in appreciable quantum locally in association with concept of complete feed technology and use of biological agents (feed additives) to maximize advantage from given feeds in animal production systems. Biological treatment is a much favorable option and is believed to be more eco-friendly and safer than the use of chemicals. Various methods of biological treatment/ fortification of paddy straw to enhance its utilization in animals include treatment with white rot fungi, ensilage with agro-industrial byproducts like apple pomace or fortification with proteins, greens or enzymes [35-38]. Although the use of white rot fungi causes significant loss of dry matter and organic matter [21,39] besides needs much more technical know and sometimes beomes impracticable at farmers level. The ensiling of straw with fruit pommace or poultry excreta or rumen liquor does not need sophisticated infrastructure with such facilities available at farmers level, but the advantage of these methods lies in fact of improving digestibility of nutrients, gain in body weight and overall performance of animals. Despite being safe and environmental friendly these biological agents have potent effect on digestibility of fodder by manipulating rumen environment. Gado et al. [40] reported decrease in the total phenolics, saponins and aqueous fraction with higher average daily gain, TDN and digestibility coefficients for DM, OM, CP, CF, NDF and ADF in Ossimi male lambs fed paddy straw ensiled orange pulp treated with exogenous enzymes diet than control. In other study Gado et al. [40] suggested a strong potential in improving digestibility and degradation of NDF and ADF of rice straw pre-treated with exogenous enzymes. Karunanandaa et al. [26,41] also reported enhanced IVDMD in both leaves and stems of rice straw by incubation with white-rot fungi (Pleurotus sajor-caju) for 30 days. However, entire rice straw (leaf and stem) treated with Cyathus stercoreus had the highest IVDMD compared to the other fungi. This improved digestibility of biologically treated straw is result of improvement in chemical composition as Akinfemi \& Ogunwole [4] evaluated chemical composition and in vitro digestibility of rice straw treated with Pleurotus ostreatus, Pleurotus pulmonarius and Pleurotus tuber-regium found significant increase in the crude protein and significant decrease in crude fibre, cellulose, neutral detergent fibre, acid detergent fibre and acid detergent lignin of fungal treated rice straw than control. Fungal treated rice straw showed higher values of minerals ( $\mathrm{Ca}$ and $\mathrm{Mg}$ ), gas volume, metabolisable energy, organic matter digestibility and short chain fatty acid were also higher in fungal treated straw than control. White rot fungi efficiently degraded the lignin and enhanced the in vitro digestibility of paddy straw [4]

In another study Ganai \& Teli [21] reported increase in CP, DCP and TDN content and nitrogen balance in Corriedale sheep fed paddy straw treated white rot fungi (Pleurotus ulmarius). Similarly Abdel-Azim et al. [42] reported that treating rice straw and corn stalks with Trichoderma viride, improved feeding value resulting in higher intake, $\mathrm{N}$ balance and growth rate in cross-bred lambs. The author also reported that DM consumption of fungal treated paddy straw was significantly higher than untreated straw. Bassiouni et al. [43] studied the effect of fibrolytic enzymes supplementation on In Situ degradability of DM, CP and CF of different rations consisted of concentrate feed mixture + berseem hay, dried sugar beet tops, corn silage, rice straw or wheat straw in different ratios 60:40or 40:60 incubated in canulated multiparous Friesian cows. Rations contained rice straw showed the lowest $(\mathrm{P}<0.05)$ values of in situ DM, CP and CF disappearance. In support of these findings Khattab et al. [37] studied chemical composition, nutritive value, in vitro digestibility and scanning electron microscopy (SEM) of rice straw (RS) and Pleurotus ostreatus spent rice straw (SRS) and reported higher protein, amino acids (mg/100g) content, in vitro dry matter disappearance (IVDMD) and in vitro organic matter disappearance (IVOMD) for SRS compared to RS while, DM, OM, NFE, CF, NDF, ADF, ADL, hemicellulose and cellulose were less for SRS than for RS. Pothiraj et al. [44] reported that fibrolytic enzymes of $A$. nigersuch as cellulase, $\beta$-glucosidase and xylanase had reduced the lignocellulose compound of the rice straw (Figure 1). 


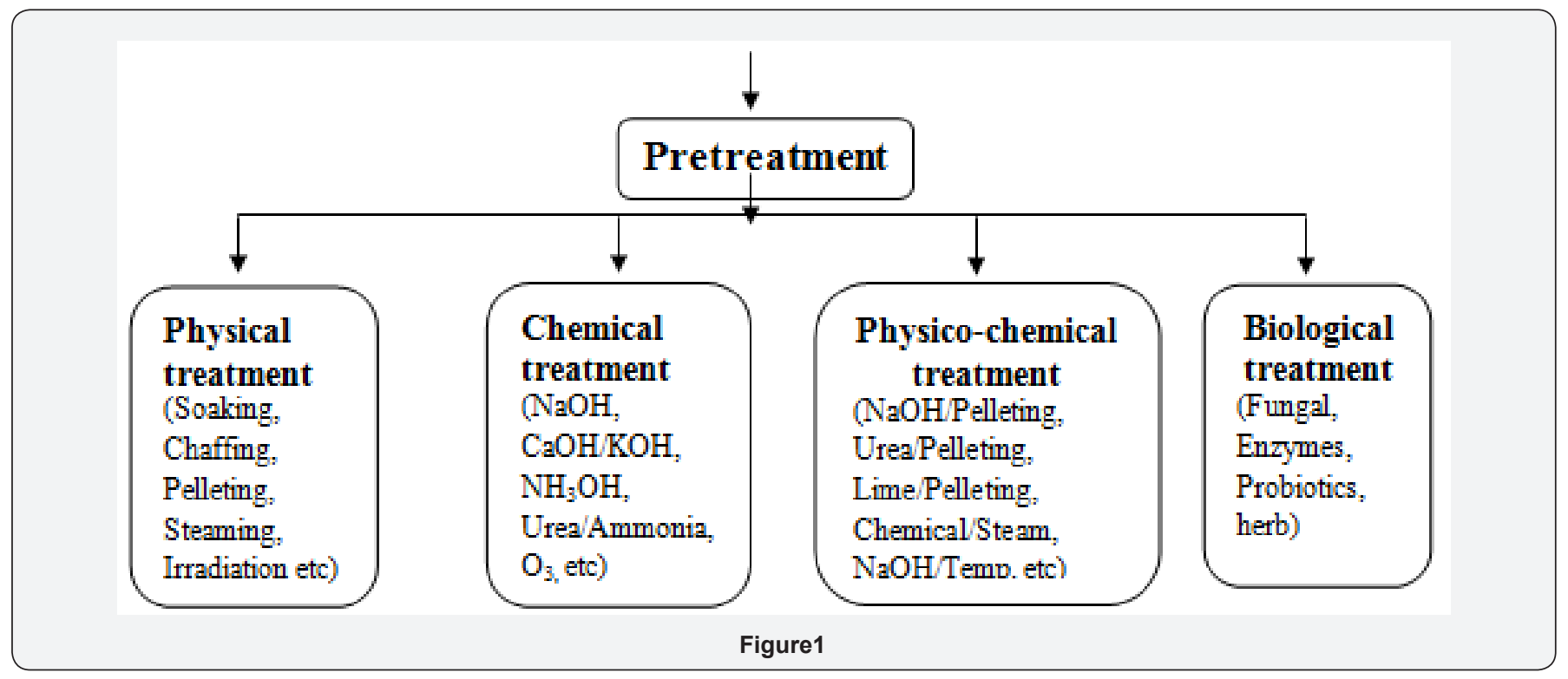

Some studies, using fibrolytic enzymes alone could not significantly increase the degradability of rice straw because the ability of these enzymes to break down the esterified bonds within lignin-carbohydrate complexes may be limited. However, when using in combination with other pre-treatments they could increase degradability and in vitro fermentation characteristics, as shown by Eun et al. [51] treated rice straw with xylanase or cellulase in combination with ammonia, Hussein et al. [52] treated rice straw with urea and commercial effective microorganisms, Liu \& Ørskov [29] treated rice straw with cellulase in combination with steam pre-treatment, Wang et al. [46] treated rice straw with multi-enzymes (xylanase, $\beta$-glucanase, carboxymethyl cellulase and amylase) in combination with $\mathrm{NaOH}$, found that the use of combinations of fibrolytic enzyme with these pre-treatments is expected to have a synergistic effect on the nutritive improvement of rice straw. evaluated use of rumen liquor, chicken manure and commercial probiotic to improve nutritional value of rice straw and reported that crude protein level of rice straw fermented with chicken manure was the highest followed by that of rumen liquor treatment and significantly different from those of commercial probiotic and control treatments. Crude fiber level of rice straw fermented with manure showed the lowest level but not significantly different from rumen liquor and commercial probiotics. These values were significantly lower than control. While assessing the effect of incorporation of wheat straw-rice straw (WS-RS in 50:50 ratio) or Pleurotus florida harvested spent WS-spent RS (50:50) in kids, Kaur et al. [47] observed a higher DM intake $(0.80$ vs. $0.65 \mathrm{kgd}$ ${ }^{1}$ ), digestibility of majority of nutrients (except cellulose which was depressed), N-retention (5.36 vs. $4.87 \mathrm{~g}$ ), apparent biological value ( 63.08 vs. $53.43 \%$ ) and daily live weight gain were comparable in both the groups. Apart from enzymatic treatment [37] reported the microbial application of rice straw degraded the lignocellulosic contents, thus improving the rumen DM degradability which would affect the weight gain of animal. By degrading the lignocellulosic contents of rice straw, more nutrients are made available for ruminal microflora, which in turn will sustain the longevity of the microbes.

More importantly, harmful microorganisms such as toxin-producing fungi that contaminate the rice straw could be suppressed by application of microbials on the feedstuff, proving its ability to restrain the growth of the harmful toxinproducing fungi. Gomaa [48] verified the potential benefits of supplementing rice straw with exogenous anaerobic bacterial enzymes (ZAD) and orange pulp for Ossimi sheep found significant $(\mathrm{P}<0.05)$ decreases in $\% \mathrm{CF}, \% \mathrm{NDF}$; while \%CP, $\% \mathrm{ADF}$ and \%ADL values increased for rations containing either ZAD, orange pulp or both. Rams fed rations containing either ZAD, orange pulp or both significantly increased $(\mathrm{P}<0.05)$ ruminal ammonia- $\mathrm{N}$, total volatile fatty acids plasma total protein with low level of gas production post feeding values. Similarly Salehpor et al. [49] evaluated the effect of rice straw processing by Lactobacillus, multi enzymes and calcium hydroxide on the digestibility and nutritional value. Each of three processing operation, reduce the amount of $\mathrm{ADF}$, cellulose and hemicelluloses in the straw. The same trend also has been in the NDF and bacterial processing has the lowest and enzymatic, chemical and control straw have the greatest amount of NDF, respectively. The amount of gas production rate in the bacterial methods was more than the other methods and with increasing incubation time, shows upward trend. Addition of lignocellulolytic enzymes and bacterial lignocellulolytic on rice straw resulted in significant improvement of all the fermentation products (volatile fatty acid, acetate, propionate, butyrate, and ammonia) between control and treatment groups. Lignocellulolytic enzymes @ 5\% 
of dry matter dose rate resulted in optimal products of volatile fatty acid and ammonia [50].

Similarly Samsudin et al. [51] found improved nutritive values of rice straw fed to goats when treated with Aspergillus niger, fungal and effective microbes (EM). No significant $(\mathrm{P}>0.05)$ difference was observed on the chemical composition of rice straw treated with $A$. niger except the $\mathrm{CP}$ content increased significantly $(\mathrm{P}<0.01)$ when compared with untreated rice straw. However, when the fungal-treated rice straw was inoculated with $\mathrm{EM}$, significant $(\mathrm{P}<0.01)$ improvement was observed in DMD, CP, OM, NDF, ADF and cellulose content of the rice straw compared with control. In other study Elmoghazy et al. [53] evaluated effect of sheep diets containing lignolytic microbiological treated (Bacillus licheniformis, Ruminococcus albus, Aspergillus oryzae, Rhizopus nigricans \& Saccharomyces cerevisiae) rice straw on blood parameters and nitrogen balance. Results exhibited that the microbiological treatments significantly decreased the DM and CF while CP was significantly increased. Regarding nitrogen balance, haematobiochemical and serum enzymes (aspartate transaminase and alanine transaminase) were not affected with microbiological treatment. The use of combinations of fibrolytic enzyme with these pre-treatments is expected to have a synergistic effect on the nutritive improvement of rice straw. Especially, the use of lignin-degrading enzymes, originating from fungi, seems a promising development. Although, application of enzymes has proven to increase the feed value of poor quality feedstuffs, its use by smallholder farmers is, for the time being, economically unattractive. However, it becomes a promising technology when used at commercial level [54-65].

\section{Conclusion}

Rice straw being the principle agro-residues in terms of volumes generated in India, is poor in nutritive value with high level of lignification and silicification. So feeding of rice straw to livestock does not provide enough nutrients even for maintenance. Rice straw is usually fed untreated without supplements in spite of the fact that many methods for improved utilization of rice straw have been developed and recommended such as physical, chemical and biological treatments. Among these methods, biological treatment is a much favorable option and is believed to be more environmental friendly and safer.

\section{References}

1. NARC newsletter (rice special issue) (2004).

2. Devendra C (1997) Crop residues for feeding animals in Asia: Technology development and adoption in crop/livestock systems. In: Renard C (Ed.), Crop Residuals in Sustainable Mixed Crop/livestock Farming System. CAB International, Wallingford, UK, pp. 241-267.

3. Devendra C, Thomas D (2002) Crop-animal interactions in mixed farming systems in Asia Agric Syst 71: 27-40.

4. Saritha M, Arora A, Naina L (2012) Pretreatement of paddy straw with Trametes hirsute for improved enzymztic saccharification bioresour technol 104: 459-65.
5. Shen HS, Ni DB, Sundstøl F (1998) Studies on untreated and ureatreated rice straw from three cultivation seasons: Physical and chemical measurements in straw and straw fractions. Anim Feed Sci Technol 73: 243-261.

6. Ganai AM, MatooFA, Singh PK, Ahmad HA, Samoon MH, et al. (2006) Chemical composition of some feeds, fodders and plane nutrition of livestock of Kashmir valley. SKUAST Journal Res 8:145-151.

7. Sharma MN, Khare A, Gupta SK (2001) Hydrolysis of rice hull by crosslinked Aspergillus nigercellulase. Bioresour Technol 78: 281- 284.

8. Van Soest PJ (2006) Review: rice straw, the role of silica and treatments to improve quality. Anim Feed Sci Technol 130: 137-171.

9. Schiere JB, Ibrahim MNM (1989) Feeding of ureaammonia treated rice straw: A compilation of miscellaneous reports produced by the straw utilization project (Sri Lanka). Pudoc, Wageningen, Netherlands.

10. Iiyama K, Lam TBT, Stone BA (1990) Phenolic acid bridges between polysaccharides and lignin in wheat internodes. Phytochem 29:733737.

11. Singh GP, Oosting SJ (1993) Nutritive value of straw. In: Singh K, Schiere JB (Eds.), Feeding of ruminants on fibrous crop residues. Indian Council of Agricultural Research, New Delhi, India, pp. 141-146.

12. Agbagla-Dohnani A, Noziere P, Gaillard-Martinie B, Puard M, Doreau M, et al. (2003) Effect of silica content on rice straw ruminal degradation. J Anim Sci 140: 183-192.

13. Bae HD, Mac Allister TA, Kokko EG, Leggett FL, Cheng KJ, et al. (1997) Effect of silica on colonization of rice straw by ruminal bacteria. Anim Feed Sci Technol 65: 165-181.

14. Doyle PT, Devendra C, Pearce GR (1986) Rice straw as a feed for ruminants. IDP, Canberra, Australia.

15. Conrad HR (1966) Symposium on factors influencing the voluntary intake of herbage by ruminants: Physiological and physical factors limiting feed intake. J Anim Sci 25: 227-235.

16. Baile CA, Forbes JM (1974) Control of feed intake and regulation of energy balance in ruminants. Physiol Rew 54:160-214.

17. Theander O, Aman P (1984) Anatomical and chemical characteristics. In: Sundstøl F, Own E (Eds.), Straw and other fibrous by-products as feed. Developments in animal veterinary sciences 14. Elsevier, Amsterdam, Netherlands, pp. 45-78.

18. Vadiveloo J (2000) Nutritional properties of the leaf and stem of rice straw. Anim Feed Sci Technol 83: 57-65.

19. Phang OC, Vadiveloo J (1992) Effects of varieties, botanical fractions and supplements of palm oil by-products on the feeding value of rice straw in goats. Small Rumin Res 6: 295- 301.

20. Vadiveloo J (1995) Factors contributing to varietal differences in the nutritive value of rice straw. Anim Feed Sci Technol 54: 45-53.

21. Ganai AM, Teli MA (2010) Nutritive value of urea and fungal treated paddy straw on nutrient utilization in sheep. Veteri Pract 11(1): 55-59.

22. Fadel Elseed AMA, Abusamra MAR (2007) Effect of supplemental yeast (Saccharomyces cerevisiae) culture on NDF digestibility and rumen fermentation of forage sorghum hay in Nubian goat's kids. Res J Agric Biol Sci 3: 133-137.

23. Abou-EL-Enin OH, Fadel JG, Mackill DJ (1999) Differences in chemical composition and fibre digestion of rice straw with, without, anhydrous ammonia from 53 rice varieties. Anim Feed Sci Technol 79: 129-136.

24. Abou-EL-Enin OH, Fadel JG, Mackill DJ (1999) Differences in chemical composition and fibre digestion of rice straw with, without, anhydrous ammonia from 53 rice varieties. Anim Feed Sci Technol 79: 129-136.

25. Reddy DV (1996) Evaluation of rice straw-poultry droppings based 
rations supplemented with graded levels of rice bran in fistulated buffaloes. Anim Feed Sci Technol 58: 227-237.

26. Karunanandaa K, Varga GA, Akin DE, Rigsby LL, Royse DJ, et al. (1995) Botanical fractions of rice straw colonized by white-rot fungi: Changes in chemical composition and structure. Anim Feed Sci Technol 55:179199.

27. Shen HS, Sundstøl F, Eng ER, Eik LO (1999) Studies on untreated and urea-treated rice straw from three cultivation seasons: 3 . Histological investigations by light and scanning electron microscopy. Anim Feed Sci Technol 80:151-159.

28. Vu DD, Cuong LX, Dung CA, Hai PH (1999) Use of urea-molassesmultinutrient block and urea-treated rice straw for improving dairy cattle productivity in Vietnam. Prev Vet.

29. Liu JX, Ørskov ER (2000) Cellulase treatment of untreated and steam pre-treated rice straw- effects on in vitro fermentation characteristics. Anim Feed Sci Technol 88: 189-200.

30. Selim ASM, Pan J, Takano T, Suzuki T, Koike S (2004) Effect of ammonia treatment on physical strength of rice straw, distribution of straw particles and particle-associated bacteria in sheep rumen. Anim Feed Sci Technol 115: 117-128.

31. Wanapat M, Sommart K, Saardrak K (1996) Cottonseed meal supplementation of dairy cattle fed rice straw. Livest Res Rural Dev $8(3)$.

32. Wanapat M, Petlum A, Pimpa O (1999) Strategic supplementation with a high quality feed block on roughage intake, milk yield and composition and economic return in lactating dairy cows. Asian-Aust J Anim Sci 12: 901-903.

33. Akter Y, Akbar MA, Shahjalal M, Ahmed TU (2004) Effect of urea molasses multi-nutrient blocks supplementation of dairy cows fed rice straw and green grasses on milk yield, composition, live weight gain of cows and calves and feed intake. Pak J Biol Sci 7(9): 1523-1525.

34. Sheikh GG, Sarkar TK, Ganai AM, Ahmad HA, Islam S (2014) Effect of feeding urea molasses impregnated paddy straw on nutrient utilization, milk yield and economics of feeding in crossbred cows. Indian J Anim Nutri 2:152-155.

35. Tiwari SP, Narang MP, Dubey M (2008) Effect of feeding apple pomace on milk yield and milk composition in crossbred (Red Sindhi x Jersey) cow. Livestock Research for Rural Development 20(4).

36. Jahromi MF, Liang JB, Rosfarizan M, Goh YM, Shokryazdan P (2011) Efficiency of rice straw lignocelluloses degradability by Aspergillus terreus ATCC 74135 in solid-state fermentation. Afr J Biotechnol 10(21): 4428-4435.

37. Khattab HM, Gado HM, Salem AZM, Camacho LM, El-Sayed MM (2013) Chemical composition and in vitro digestibility of Pleurotus ostreatus spent rice straw. Anim Nutri and Feed Techn 13: 507-516.

38. Khatooni MA, Nobar RSD, Cheraghi H (2014) Evaluating possibility replacement of by-product of apple pomace with barley grain for ruminants by in vitro gas production technique. J animl Sci Adv 4(5): 839-844.

39. Shrivastava B, Jain KK, Kalra A, Kuhad RC (2014) Bioprocessing of wheat straw into nutritionally rich and digested cattle feed. Scientific Report (4).

40. Gado HM, Salem AZM, Odongo NE, Borhami BE (2011) Influence of exogenous enzymes ensiled with orange pulp on digestion and growth performance in lambs. Anim Nutr Feed Technol 165: 131-136.

41. Karunanandaa K, Varga GA, Akin DE, Rigsby LL, Royse DJ, et al. (1995) Botanical fractions of rice straw colonized by white-rot fungi: Changes in chemical composition and structure. Anim Feed Sci Technol 55:179199.
42. Abdel-Azim SN, Ahmed MA, Abo-Donia F, Soliman H (2011) Evaluation of fungal treatment of some agricultural residues. Egypt J Sheep Goat Sci 6:1-13.

43. BassiouniMI, Gaafar HMA, Mohi AAA, El-Din, Metwally AM, et al. (2011) Evaluation of rations supplemented with fibrolytic enzyme on dairy cows performance 2 . In situ ruminal degradability of rations containing different roughages at two concentrate to roughage ratios. Researcher 3: 21-33.

44. Pothiraj C, Balaji P, Eyini M (2006) Enhanced production of cellulases by various fungal cultures in solid state fermentation of cassava waste. Afr J Biotechnol 5:1882-1885.

45. Eun JS, Beauchemin KA, Schulze H (2006) Use of an in vitro fermentation bioassay to evaluate improvements in degradation of alfalfa hay due to exogenous feed enzymes. Anim Feed Sci Technol 135: 315-328.

46. Wang Y, Spratling BM, ZoBell DR, Wiedmeier RD, McAllister TA, et al. (2004) Effect of alkali pre-treatment of wheat straw on the efficacy of exogenous fibrolytic enzymes. J Anim Sci 82:198-208.

47. Kaur K, Wadhwa M, Bakshi MPS (2010) Nutritional evaluation of Pleurotus florida harvested spent wheat-rice straw based diets in goats. Indian J Anim Sci 80: 906-909.

48. Gomaa R, Gado HM, El-Sayed H, Abd El Mawla S (2012) Usage of treated rice straw with exogenous anaerobic bacterial enzymes (ZAD) for Ossimi sheep. Annals of Agricultural Sciences 57: 183-190.

49. Salehpor S, Rasouli B, Ghotbi AA (2012) Evaluation of digestibility and nutritional value of processed rice straw by bacterial, enzymatic and chemical methods with gas production and chemical methods. Research Journal of Applied Sciences Engineering and Technology 4(13): 1992-1996.

50. Lamid M, Ni Nyoman TP, Sarwoko M (2013) Addition of Lignocellulolytic Enzymes Into Rice Straw Improves In Vitro Rumen Fermentation Products. J Appl Environ Biol Sci 3(9): 166-171.

51. Samsudin AA, Masori MF, Ibrahim A (2013) The effects of effective microorganisms (em) on the nutritive values of fungaltreated rice straw. Mal J Anim Sci 16(1): 97-105.

52. Hussein SSA, Alimon AR, Mohamad NI, Nurzillah M, Haryani H (2012) Improving the energy values of rice straw and oil palm empty fruit bunch in ruminant feeding. Malaysian Journal of Veterinary research 3: 57-64.

53. ELmoghazy M, Husain M, El-Fadaly, Tag EL-Din H, Tag EL-Din, et al. (2015) Effect of sheep diets containing microbiological treated rice straw on blood parameters and nitrogen balance. Journal of Microbiology Research 5(2): 46-56.

54. Akinfemi A, Ogunwole OA (2012) Chemical Composition and in vitro digestibility of rice straw treated with Pleurotus ostreatus, Pleurotus pulmonarius and Pleurotus tuber-regium. Slovak Journal of Animal Science 45:14-20.

55. Annonymous (2013-14) Economic Survey, Directorate of Economics and Statistics, Jammu and Kashmir Government, Srinagar, India.

56. Gado HM, Salem AZM, Camacho LM, Elghandour MMY, Salazar MC (2013) Influence of exogenous enzymes on in vitro ruminal degradation of ensiled rice straw with DDGS. Anim Nutr Feed Technol 13: 569-574.

57. Hossain MM, Khan MJ, Akbar MA (2010) Nutrient digestibility and growth of local bull calves as affected by feeding urea and urease enzyme sources treated rice straw. Bang J Anim Sci 39: 97-105.

58. Karunanandaa K, Fales SL, Varga GA, Royse DJ (1992) Chemical composition and biodegradability of crop residues colonized by white rot fungi. J Sci Food Agric 60:105-112.

59. Maqbool SB, Riazuddin S, Loc NT, Gatehouse AMR, Gatehouse JA (2001) 
Expression of multiple insecticidal genes confers broad resistance against a range of different rice pests. Mol Breed 7: 85-93.

60. Prasad CS, Sampath KT, Shivaramaiah MT, Walli TK (1993) Dry matter intake, digestibility and supplementation of slender and coarse straws-A review. In: K Singh, JB Schiere (Eds.), Feeding of ruminants on fibrous crop residues. Indian Council of Agricultural Research, New Delhi, India, pp.188-203.

61. Sharma RK, Arora DS (2010) Production of lignocellulolytic enzymes and enhancement of in vitro digestibility during solid state fermentation of wheat straw by Phlebia floridensis. Bioresour Technol 101: 9248-9253.
62. Vadiveloo J (1992) Varietal differences in the chemical composition and in vitro digestibility of rice straw J Agric Sci 119: 27-33.

63. Vadiveloo J (2003) The effect of agronomic improvement and urea treatment on the nutritional value of Malaysian rice straw varieties. Anim Feed Sci Technol 108: 33-146.

64. Warly L, Matsui T, Harumoto T, Fujihara T (1992) Study on the utilization of rice straw by sheep: Part I. The effect of soybean meal supplementation on the eating and rumination behavior. Asian-Aust J Anim Sci 5: 695-698.

65. NARC newsletter May 2013.

\section{Your next submission with Juniper Publishers will reach you the below assets}

- Quality Editorial service

- Swift Peer Review

- Reprints availability

- E-prints Service

- Manuscript Podcast for convenient understanding

- Global attainment for your research

- Manuscript accessibility in different formats

(Pdf, E-pub, Full Text, Audio)

- Unceasing customer service

Track the below URL for one-step submission https://juniperpublishers.com/online-submission.php 